\title{
109 円弧歯形歯車の開発
}

\section{（第 1 報 円弧歯車の特徵・強度）}

Development of the Symmetrical aec gear

(1st Report The characteristic and the strength of the arc gear)

\section{日本工大 $\bigcirc$ 能上允男＼cjkstart有賀幸則ハセックギア 山田昌三}

\begin{abstract}
Masao NOGAMI Nippon Institute of Technology , Miyashiro Saitama
Yukinori ARIGA Nippon Institute of Technology, Miyashiro Saitama Syouzou YAMADA Hasegawa Gear Works, Sawara Chiba
\end{abstract}

As for the resarch of the arc tooth gear, formerly, a lot of research was done. However, it is several kinds that are only practicalized. For example, it is the Novkov gear of former USSR, Circarc gear in the United Kingdom and then Logix gear in Japan and so on. The arc tooth gear of the authors is a point symmetrical arctooth gear to the pace point, having the tooth end arc and a tooth origin arc to one tooth. In this repot, it report on the performance of this symmetrical arc tooth with gear.

Key Words : Gear, Arc Tooth, Strength, Charcacteristical

\section{1.はじめに}

円弧歯形歯車の開発研究から歯形の修整、そして実機歯 車の追跡調查、トラブルの解明などを写真などを使用して 説明報告する。この円孤歯形系歯車は、1960 年旧西独 のエッセンで開催された国際歯車会議で $\mathrm{W} / \mathrm{N}$ 歯車と呼ば れ、この名が国際的に一番通り易い ${ }^{1)}$ 。この由来は、19 26 年、米国の E.ウィルードハーバ博士が初めて考えて特 許を出したことと 1955 年、旧ソ連の M.L.ノービコフ博 士が一般的産業機械に実用したことで、両者の偉業を讃え て、頭文字取ったことによる。

日本では、 1956 年、当時、日立製作所の保延誠博士 が一つの歯に歯末円弧と歯元円弧を有する円弧歯形歯車を 実用解析して日本、米国、独国、英国の特許を取得して ${ }^{2)}$ 、 5000 台以上の一般産業用減速機や製鉄所の圧延機に実 用されている。この歯車は、一つの歯に歯末円弧と歯元円 弧を有しピッチ点に対して点対称歯形であることから Symmetrical Arc からシンマーク歯車 (日立製作所、商標) ${ }^{3)}$ の商標で実用化されている。この歯車を便宜的に $\mathrm{S}$ 一円弧 歯車（S-Arc Gear）と呼ぶことにする。

英国の旧 AEI 社では、一つの歯に歯末か歯元円弧しか有 しない非対称形の円弧歯車を浸炭焼入れ研削してヘリコプ 夕の回転翼の最終減速歯車に実用開発を進めていて、採用 を確定し、生産に入っている(推定されるK值 $15 \mathrm{MP}$ a)。 2. 円弧歯形の種類

円弧歯形の種類は、大別して図 1 に示す 3 種類である。

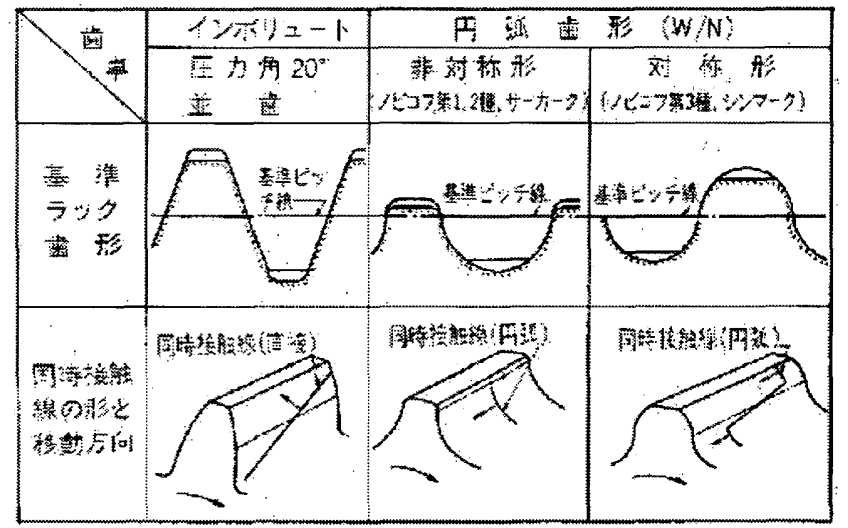

Fig.1 Types of Arc Tooth Gear
旧ソ連では、第 1 種を小歯車が歯末円弧のみで、大歯車が 歯元円弧のみである。第 2 種が第 1 種と反対で、小歯車が 歯元円弧のみで大歯車が歯末円弧だけで構成されている。 第 3 種は、一つの歯に歯末円弧と歯元円弧がある歯形であ る。S-円弧歯車は、ノービコフ第 3 種に属し、英国のサー カーク歯車は第 1 種に属する。旧ソ連では、主に第 1 種歯 形が使われていた。

\section{3. $\mathrm{s}$-円弧歯車の歯形}

$\mathrm{S}$ 一円弧歯車の基準ラック歯形を図 2 に示す。歯末の円弧 と歯元円弧があり、2つの円弧を結ぶ直線部から構成され ている。円弧の中心はピッチ点にある。ピッチ線近傍の直 線は、歯末円弧と歯元円弧を干涉させないためである。 $\mathrm{S}$ 円弧歯車は、歯形の円弧中心がピッチ点に一致した瞬間に だけ円弧の接触線が生じ、つぎの瞬間離れる。したがって、 円弧歯形歯車は、はすばで有る必要がある。歯のかみあい は、接触線が歯すじ方向に転がり移動することによって行

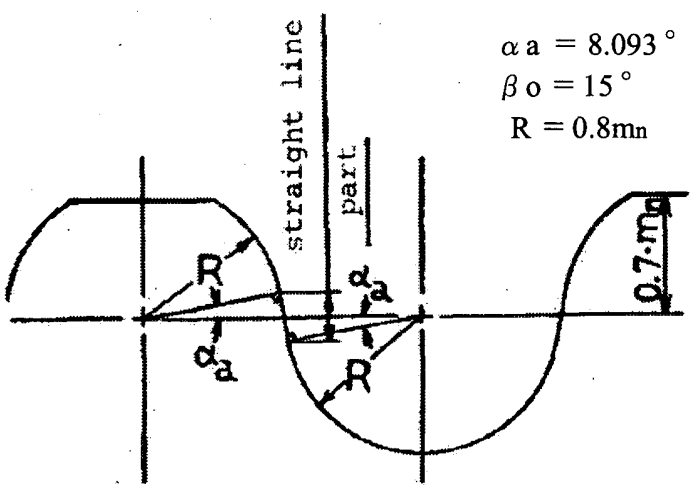

Fig.2 Basic Rack of Symmetrical Arc Tooth Gear

われる。また、等速伝達を確保するためには、重なりかみ あい率が対称形で 0.5 以上、非対称形で 1 以上であること が必要である。

4. $\mathrm{S}$ 一円弧歯車の特徴

$\mathrm{S}$ 一円弧歯車の一番の長所は、面圧に強いことである。 歯たけに沿った円弧状の接触線が負荷されることによって 歯すじ方向に大きく広がり大きな領域になり、面圧強度を 高めるわけである。また、非対称円弧歯形に比べて、S一

[No. 04-17] 日本機械学会機素潤滑設計部門 MPT2004 シンポジウムく伝動装置＞講演論文集 [2004.11.26〜27] 
円弧歯車は、 0.5 軸方向ピッチ間隔で同時接触領域が存在 するので強度的に上である。 $\mathrm{S}$ 一円弧歯車は、同時接触領 域が歯すじに移動してかみあいが行われる。そのために、 歯すじ方向の諸元（軸の平行度など含めた歯すじ方向誤差、 重なりかみあい率、歯幅、㸚じれ角など）を重視しなけれ ばならない4（5)。これは、インボリュート平歯車のかみあ いに置き換えると正面歯形の諸元に相当する。

一方円弧歯車は、中心距離の誤差が負荷能力に敏感に影 響するという問題がある。 $\mathrm{S}$-円弧歯車の中心距離と歯当 たりの関係を図 3 に示す。中心距離が正規の状態 (Fig3-b)、 時は、歯先から歯元に接触線が生じる。しかし、中心距離 が正規の状態よりも短くなると歯先と歯元の 2 点当たりに なり (Fig3-a)、長くなるとピ.ッチ点近傍の 1 線当たりになる (Fig3-c)。このピッチ点近傍は、歯末円弧と歯元円弧を結び、 干涉を避けるために短い直線（歯車としてはインボリュー 卜曲線）部分になっており、表面疲れの弱い部分である。

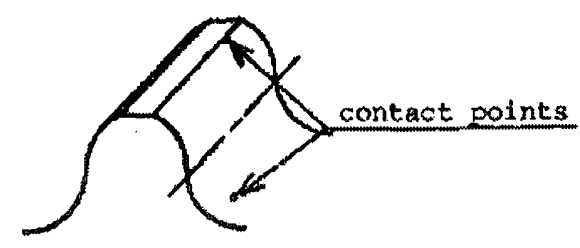

(a) shorter center distance

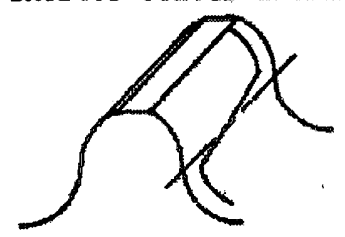

(b) theoretical ("normal") center distance

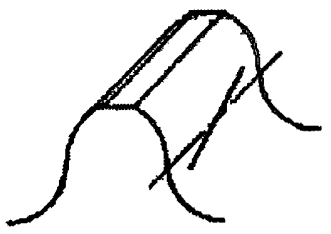

(4) Lonyer center distance

Fig.3 Relation between Center Distance and Tooth Bearing

5. $\mathrm{S}$ 一円弧歯形歯車の強度・性能

$\mathrm{S}$ 一円弧歯車の強度をまとめると次の様になる。

5. 1 表面疲れ強さ ${ }^{6)}$

$\mathrm{S}$ 一円弧歯車の特長は、表面疲労に強いことである。実験 室では、インボリュート歯車の約 3 倍である。これは、歯 末円弧（凸円弧）と歯元円弧（凹円弧）が相手歯車の歯元 円弧と歯末円弧とかみあい、また、この接触領域が、負荷 されることによって歯すじ方向に大きく広がるためである。 また、油膜構成がし易い。これは、接触線（接触領域）の 移動速度が速いためである（未検証）。

5.2 曲げ強さ7

曲げ強度は、インボリュート歯車の約 1.3 倍と余り強く ない。これは、S 一円弧歯車は歯丈が約 1.5 モジュールと 低歯であり、歯元の半径が大きく歯元の応力集中が緩和さ れるためである。その反面、歯車のかみあいが、インボリ
ユート歯車でいう片当たりに似ているからである。しかし、 曲げ強さが問題になる高負荷では、接触領域が歯すじ方向 に大きく広がり強くなる。また、 $\mathrm{S}$ 一円弧歯車は、最少歯数 が 7 枚であるので、設計に当っては歯数を少なくしてモジ ュールを大きく取り、曲げ強さを上げることが出来る。

5. 3 騒音・振動

歯車の振動・騒音は、歯形とかみあいの特徵から、大き くする要因と小さくする要因があり、歯車諸元の取り方で 決まる。特に重なりかみあい率の定め方が重要である。歯 切りカッタの精度を高めて、適切な設計をすることのよっ て、騒音レベルが以前より、実験室的には、6〜10 d B (A)

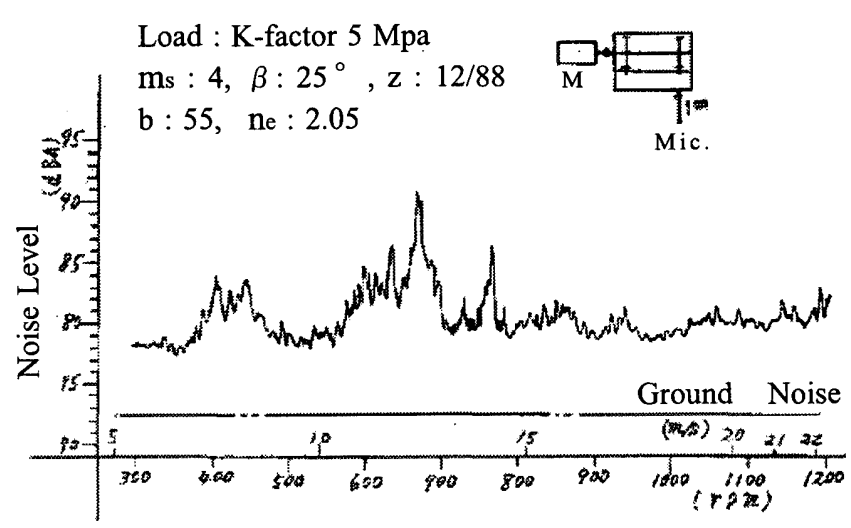

Fig.4 Noise of S-Arc Geat

低下した。また、 X - Y レコーダで回転速度と騒音レベル を同時記録した結果を図 4 に示すように、ピッチ円周速度 が $5 \sim 22 \mathrm{~m} / \mathrm{s}$ の範囲で速度が上がっても騒音レベルの 上昇が少ないことが確認されている。また、実機において も、騒音が高いという指摘と低いという指摘の、両方の話 がある。ある形鋼の圧延メ一カに S 一円弧歯車減速機の調 查に行った時に、顧客から、余りに静かなので、稼働して いるのか、停止しているのか分からないので、怖いと言わ れたこともあった。周囲に設置されている他の減速機がう るさくて、S - 円弧歯車減速機の直ぐ側に行かないと、運転 されている音が聞こえないこともあった。

6.おわりに

以上、 $\mathrm{S}$ 一円弧歯車の強度・性能を定性的に述べたが、 詳細は、参考文献を参照されれば幸いに思う。第 2 報では、 これらの研究の裏付けにより、実機に採用したものの、追 跡調査と予期しなかったトラブルに遭遇したことについて 報告する。

\section{参考文献}

1）保延: 機械学会、第 432 回講習会（機械要素の最近 の進歩)

2) 特許 No 254718 食い違い軸又は交差軸の円弧歯 形捻九歯車 ( 1959 )

3) 商標 No.929009（R）シンマーク (1 979 1)

4) 能上: 機械学会、第 8 回シンポジュウム（１９９７５）

5 ) 能上、糟谷: 機械設計（日刊工業新聞社）新しい歯車 とその応用、第 26 巻第 3 号 ( $\left.\begin{array}{llll}1 & 9 & 8 & 2\end{array}\right)$

6 ) 糟谷他 3 名 : Journal of Mechanical Design Vol.1.103

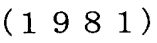

7 ) 能上: 機械学会、九州支部講演論文集 (1.974) 